\title{
The Elephant's Graveyard: Spectres of the Abyss?
}

\section{Barbara Creed}

And when you gaze long into an abyss, the abyss also gazes into you.

Frederich Nietzsche ${ }^{1}$

What is the abyss? Various definitions refer to it as primal chaos, the bottomless pit, a yawning gulf, an unfathomable chasm, an immeasurably profound depth or void - night, space, darkness. Some poets, painters and writers tell us it is death itself. All societies have a concept of the abyss or death, of that which terrifies but also fascinates. The nineteenthcentury German philosopher, Frederich Nietzsche, famously said: 'And when you gaze long into an abyss, the abyss also gazes into you.'2 For Nietzsche, the abyss signifies a yawning gulf, nihilism, a world without meaning, truth and purpose. The individual who is unable to give meaning to the world, through interpretation, faces the abyss. Artist Dan McEwen explored Nietzsche's concept of the abyss with a work titled When you gaze into the abyss, and the abyss stares back at you, do you blink? The figure in McEwen's work appears to be in a womb-like space, surrounded by darkness. The womb is central to an understanding of the abyss, as I shall discuss shortly in this exploration of the relationship between art and the abyss, where I ask 'What is the origin of our fascination with the eternal abyss and its influence on the spark of imagination?'

The main issue I wish to pursue concerns the relationship between the abyss and other species. Here I am defining the abyss as a signifier of an unfathomable chasm, death and nothingness. Why have we-as human animals - constructed 
such a concept? Are we the only species to do so? Why does the abyss inspire such a powerful range of emotions? How do artists represent animals in relation to the abyss? The influential and anthropocentric seventeenth-century French philosopher, René Descartes, argued that non-human animals not only lack intelligence and emotions but the ability to understand death, even their own deaths. ${ }^{3}$ Animals, he argued, were like automata, machines without feeling or reason. According to Nicolaas Rupke the theory of the animal as 'beast-machine' grew in favour after Descartes' death and was taken up in medical and ecclesiastical circles. ${ }^{4}$

In his eyewitness account of eighteenth-century practices, Nicolas Fontaine wrote that in the belief that animals were automata they were beaten 'with the utmost indifference'. The cries they emitted were regarded as the sounds that might be made by a machine. Fontaine wrote:

[They] nailed the poor animals to boards by the four paws to dissect them while still alive, in order to watch the circulation of the blood, which was a great subject of discussion. ${ }^{5}$

Voltaire, the eighteenth-century French Enlightenment philosopher, responded to Descartes' view that animals were automata:

Barbarians seize this dog, which in friendship surpasses man so prodigiously; they nail it on a table, and they dissect it alive in order to show the mesenteric veins. You discover in it all the same organs of feeling that are in yourself. Answer me, machinist, has nature arranged all the means of feeling in this animal, so that it may not feel? Has it nerves in order to be impassible? Do not suppose this impertinent contradiction in nature. ${ }^{6}$

Descartes' view had profound moral consequences for the treatment of animals in future centuries. In response to Descartes, Jeremy Bentham famously wrote:

But a full grown horse or dog is beyond comparison a 
more rational, as well as a more conversable animal, than an infant of a day, or a week, or even a month old. But suppose the case were otherwise, what would it avail? The question is not, Can they reason? nor, Can they talk? But, Can they suffer? ${ }^{7}$

The practice of live vivisection continued into the nineteenth century. In 1832, Emile-Edouard Mouchy painted a work titled A Physiological Demonstration with Vivisection of a Dog in which a group of men crowd around an operating table, watching the vivisection of the animal which, because it was presumably without feelings, was not given an anesthetic. Deaf to the agonised cries of the dog, it is the scientists who appear unable to express any emotions. Charles Darwin's publication The Expression of Emotions in Man and Animals (1872) presents a very different view from that of Descartes. ${ }^{8}$ Darwin argued that the emotions evolved in human and animal alike and that animals experience almost all the emotions expressed by the human animal. If we agree with Darwin that animals share many emotions expressed by humans including fear, distress and grief, why wouldn't animals have a comprehension of death? The Cartesian view helps explain why it is that the human animal sees itself as endowed with a finer range of sensibilities than non-human animals, including the supposedly unique ability to understand the meaning and inevitability of death. Various philosophers and authors, from Martin Heidegger to Georges Bataille, have argued that this is what distinguishes human from animal. Only man is aware of his impending death - of the abyss.

All animals experience pain and terror. How can we say with confidence that they do not also have a knowledge of the abyss? Of their own deaths? Elephants we know engage in mourning rituals over their dead as well as conducting burial ceremonies. ${ }^{9}$ What then is the significance of the narrative of the Elephant's Graveyard - that fabled place to which all elephants journey when they know they are about to die? Many creatures such as apes, rhinoceros and dolphins express grief at the loss of a partner or offspring. Some creatures, including snakes, beetles and spiders will feign death, or play possum, when presented with a threat. What does it mean to 
say that animals do not comprehend death? How do artists represent the abyss and emotions in relation to animals?

The abyss takes many forms. To some it signifies fear and dread. To others an encounter with the abyss is essential to self-knowledge. Here I will first consider a number of ways in which scientists, artists, writers and filmmakers have represented the abyss, before discussing animals and death.

\section{The abyss as a black hole}

Scientists have confirmed that there is an immense black hole at the centre of the Milky Way that forms a Galactic centre. These holes emerge when massive stars collapse and die. Black holes possess such a powerful gravitational pull that not even light can escape. Surrounding the black hole is an area known as an 'event horizon' which signifies a point of no return. The language scientists use to describe a black hole ('collapse', 'point of no return') points to death as an end-event. Black holes have also signified birth. One of the Mayan myths about the centre of the Milky Way describes it as darkened by dust and gasses. The Mayans did not know what caused the dark fissure or rift but they thought it resembled alligator jaws, which to them suggested a birthing womb. Hence they described the center of the Milky Way as a birthing place; here life was born from the jaws of the alligator, or a toothed abyss. Some writers and theorists argue that modern science has inadvertently created a new form of the abyss. In his book Science Religion and the Meaning of Life, Mark Vernon asks if evolution, science and modernity have killed God for all time. ${ }^{10}$ If the answer is yes, then, he argues, that the death of religion will leave behind nothing but a void.

\section{The abyss as destructive/creative whirlpool}

In 1841 Edgar Allen Poe wrote a short story, A Descent into the Maelstrom, a tale about a man who survived a shipwreck and a whirlpool. The 1919 cover of his book was illustrated by Harry Clarke who represented the maelstrom as a massive black hole. Poe's tale is a story within a story told by an old man to the narrator. The old man tells of the fishing trip he embarked upon with two brothers. When they encounter a maelstrom the two brothers react very differently. One brother 
is driven mad by the horror of the spectacle and drowns. The other brother sees the maelstrom as a beautiful and awesome creation. He clings on to a cylindrical barrel and is saved.

Never shall I forget the sensations of awe, horror, and admiration with which I gazed about me. The boat appeared to be hanging, as if by magic, midway down, upon the interior surface of a funnel vast in circumference, prodigious in depth and whose perfectly smooth sides might have been mistaken for ebony, but for the bewildering rapidity with which they spun around...11

Poe's A Descent into the Maelstrom presents two opposing views of the dark, swirling whirlpool: in one it is a destructive space while in the other a terrifying but positive, regenerating space.

A number of artists have let the abyss fire their imagination creatively. Siberian artist Victor Lysakov in his painting The Abyss (2006), has responded to the concept of formlessness within the abyss and depicted the abyss as a free-floating space in which ghostly figures with blackened eye-sockets hover at the edges of the frame. J.M.W Turner explored the abyss in his painting, Snow Storm: Steam-Boat off a Harbour's Mouth (1842). Turner draws the viewer's eye into the centre of the scene where the storm swirls in a savage frenzy, suggesting various motifs from whirlpool to black hole. The painting seethes with energy and vitality. Edward Munch's The Cry or The Scream (1893) offers a powerful image of a personal abyss, characterised by existential anguish, which many at the time saw as central to the sensibility of the modern industrial era. The dominant use of dark wavy lines suggests loss of stability. The two men in top hats and coats, standing upright in the background represent civilisation; they are not aware of the terror perceived by the subject in the foreground. The open mouth of the androgynous figure on the bridge suggests an inner abyss, which is visually reinforced by the black swirling vortex to the right of the frame. Civilisation is fragile and it is threatened on all sides by the abject. It is thought that Munch was inspired by the sight of an erupting volcano-Mount Krakatoa. He wrote that as the sky turned blood red: 'I stood 
there trembling with anxiety. I sensed an infinite scream passing through nature.'12 In Munch's work the anguished cry seems to signify only the horror of the darkness within the self. Surrealist Rene Magritte's The Flowers of the Abyss (1928) depicts a dark world/womb where flowers look like floating spherical objects, which appear to be mechanised, even self-assembling. Here the abyss gives birth to a surreal imagination.

The cinema has always been fascinated with images of the abyss. In his classic film, Vertigo (1958), Alfred Hitchcock explored the abyss as a spiral which represented a deep hole, a vanishing point. Overcome by vertigo, the hero is in constant fear of falling into the abyss, which Hitchcock also associated with woman. To the hero, falling in love is akin to losing one's footing and falling to one's death. Hitchcock depicts the heroine as an eternal mystery, an unknowable and dangerous sexual other. She wears her hair coiled in a bun. In one scene she sits in an art gallery staring at a painting of another woman, who wears her hair in an identical bun. Hitchcock focuses on the black whorl of the bun, which seems to beckon ominously the hero. Vertigo depicts woman's sexuality as dark and mysterious - a potentially fatal abyss - which he must address if he is to experience love and passion.

In some schools of yoga the abyss is central to personal enlightenment. The individual must experience the abyss within before he or she can continue on their journey towards self-knowledge.

Surrounding the second and the third chakra is the Void which stands for the principle of mastery (guru principle) within us. In many spiritual traditions, this area is the 'ocean of illusions' that needs to be crossed with the help of a spiritual guide. When the Kundalini is awakened and passes through the Void, this principle of mastery is established within us. ${ }^{13}$

Hegel refers to the unconscious workings of the subjective spirit as a 'nightlike abyss'. In his book on Hegel, The Unconscious Abyss, Jon Mills argues that Hegel anticipated Freudian psychoanalysis and its focus on the abyss within. To 
Mills the, 'noctural' or unconscious abyss is 'an indispensible aspect of Hegel's philosophy'. ${ }^{14}$ Mills conceptualises Hegel's abyss as signifying both death and life:

There is a real horror of merging with the collective, for all individuality is annulled. This may truly be the double reality of the unconscious - the abyss is universal: in the soul and in Absolute Spirit, all particularity is annihilated. The abyss then becomes the face of death - pure negativity, nothingness. But it is precisely death that is the midwife of life. ${ }^{15}$

\section{The abyss and woman's body.}

Woman's body is associated with the abyss in both positive and negative ways. One of the most ancient representations of woman as black hole is the ancient Sheela-na-gig, from the eleventh and twelfth centuries, a figurative carving found on churches and castles in Ireland and Britain. These carvings depict a woman pulling her labia apart to revel the entrance to the vagina, which appears as a large gaping maw. This was said to be so terrifying it could ward off death and evil. The popular superstition was that when woman shows the devil her vagina, he is terrified and runs away. In ancient times, soldiers painted images of a woman's vagina on their shields to frighten the enemy. In Eros and the Abyss, religious philosopher Grace Jantzen argues that the traditional association of women with the womb as abyss needs to be rethought:

What I am suggesting is not a refutation of nihilism but a reconfiguration of its imagination. If the womb of the abyss is imagined not in misogynistic, hellish terms but rather in terms that value gender difference, embodiment, creativity and natality, then those aspects of the Abgrund which have been seen as implying the loss of all values are transformed into possibilities of new growth. ${ }^{16}$

Judy Chicago's The Dinner Party (1974-1979) is an installation artwork with dinner settings for thirty-nine mythical and famous women at a triangular table. It measured forty-eight feet on each side. Each woman was represented by a dinner 
plate that was elaborately fashioned as a vulva symbol. In many settings the vagina is represented creatively as a flowering; in others, such as the Georgia O'Keefe and Elizabeth Blackwell plates, the suggestion of the vagina-as-abyss is both clear and confronting. In The Monstrous-Feminine, I explored the representation of woman in the horror film. Although woman is almost always aligned with the primeval black hole, her generative powers are also represented as simultaneously terrifying and empowering:

What is common to all of these images of woman in discourses of horror is the voracious maw, the mysterious black hole which signifies female genitalia as a monstrous sign which threatens to ... incorporate everything in its path. This is the generative archaic mother, constructed within patriarchal ideology as the primeval 'black hole, the originating womb which gives birth to all life. ${ }^{17}$

\section{Kristeva: abjection and the abyss}

In her book Powers of Horror: Essays on Abjection theorist Julia Kristeva draws a clear connection between the abyss and the abject. According to Kristeva, the abject is that which does not 'respect borders, positions, rules' that which 'disturbs identity, system, order'. ${ }^{18}$ The place of the abject is 'the place where meaning collapses'- the abyss, the black hole. ${ }^{19}$ The abject threatens the civilised and upright-it must be forcibly excluded from the place of the living subject, separated from the body and located on the other side of an imaginary border, which separates the self from that which undermines the self. Yet we need the abject precisely so we can define what it does mean to be human and civilised. Thus the abject-as with all taboo things - terrifies yet fascinates us. What kind of things are abject? In our culture, bodily wastes are particularly abject. The proper upright subject is taught to keep his or her body clean and separate from all bodily wastes such as blood, shit, urine, mucus and pus. The most abject thing of all is the corpse. Kristeva says:

Such wastes drop so that I might live, until, from loss to loss, nothing remains in me and my entire body falls 
beyond the limit - cadere, cadaver (to fall). If dung signifies the other side of the border, the place where I am not and which permits me to be, the corpse, the most sickening of wastes, is a border that has encroached upon everything. It is no longer I who expel. 'I' is expelled. ${ }^{20}$

The corpse is a waste. In this context death signifies a terrifying form of the abyss. Death is where the body loses its footing, falls from a proper and upright place into the abyss, a place without any borders or boundaries, which opens up to receive the body. The abyss is the grave - the black hole from which the body can never extricate itself. In death, the body loses all shape and definition, finally it becomes one with the earth, with the natural world.

In Kristeva's theory, nature and the animal are also abject things. Kristeva states: 'The body must bear no trace of its debt to nature...'21 The proper civilised body should not signify the natural world. The human body of the civilised realm is upright, hairless, smooth, clean - there should be no trace of its animal origins, of the earth, of the struggle to survive. It is woman's body, however, that signifies the animal more than the male body. This is because of woman's closer ties with the animal world through the shared stages of reproduction. As with many female animals, woman is impregnated, her body changes shape, she gives birth, bleeds, lactates. Woman's bodily boundaries are more malleable, fluid and changeablemore abject. Does this mean that woman who is closer to nature, whose body is also represented as signifying the abyss is actually closer to, more intimately aligned, with the abyss?

\section{Abjection and the artist}

It is the role of the poet and artist, Kristeva says, to enter the abyss, and to confront the abject, in order to renew the social bond, to affirm self and civilisation. Does this mean that women artists explore the abyss differently from their male counterparts? Kristeva argues that, historically, it has been the function of religion to purify the abject but in modern secular societies, the work of purification is now the task of 'that catharsis par excellence called art'. ${ }^{22}$ 
In a world in which the Other has collapsed; the aesthetic task-a descent into the foundations of the symbolic construct-amounts to retracing the fragile limits of the speaking being, closest to its dawn, to the bottomless 'primacy' constituted by primal repression. ${ }^{23}$

This is a crucial function of much art-purification of the abject through a 'descent into the foundations of the symbolic construct', through a descent into the abyss. Thus an encounter with abject things (bodily wastes, death, the corpse, cannibalism, animals) effects a renewal of the individual's sense of self and civilisation. Hence, the abject is essential to the process of defining and safeguarding what constitutes the self. The subject, constructed in/through art, through desire or meaning, is also spoken by the abject, the place of meaninglessness - thus, the subject is constantly drawn to the abject, the abyss, which fascinates but which must be repelled for fear of self-annihilation.

\section{Abjection and animals}

In his essay 'Why look at animals?', John Berger argues that in our attempt to differentiate ourselves from animals - partly in response to Descartes' theory that the non-human animal is a machine without reason and emotions - we have marginalised animals and isolated ourselves. ${ }^{24}$ As Kelly Oliver writes, 'if we are capable of having only true encounters with other human beings, aren't we as John Berger might say, as a species alone in the world?'25 Yet, Berger argues, we continue to seek that close relationship, 'the first circle' we once experienced with animals, which to a large extent has been destroyed by the advent of capitalism.

The nineteenth century, in western Europe and North America saw the beginning of a process, today being completed by twentieth century corporate capitalism, by which every tradition which has previously mediated between man and nature was broken. Before this rupture, animals constituted the first circle of what surrounded man. ${ }^{26}$

He argues that as animals continue to disappear from daily 
life we reinstate them in a variety of ways: as cultural objects, as captive in zoos, as pets, and on our television and cinema screens.

Therein lies the ultimate consequence of their marginalisation. That look between animal and man, which may have played a crucial role in the development of human society, and which, in any case, all men had always lived until less than a century ago, has been extinguished. ${ }^{27}$

All animals, including ourselves, are creatures who are vulnerable in the face of death. If we believed that animals, like ourselves, also had a sense of the abyss, understood death, would we behave differently towards them?

The legend of 'The Elephant's Graveyard' holds that when an elephant realises that it is about to die, it separates itself from the group and sets out for a communal graveyard known only to the elephant world. There the elephant dies, surrounded by the bones of countless others of its kind. The elephant's graveyard is in fact a myth, first popularised in early films such as the Tarzan movies and the jungle adventure film, Trader Horn. The origin of the myth may well relate to the human fantasy of an El Dorado, a place of fabulous wealth such as a treasure trove of ivory. Yet it is also possible that we have constructed this myth because, deep down, we know that animals do understand the significance of death. We know for instance that elephants have death rituals.

In his book, Elephant Destiny, Martin Meredith recounts a typical elephant burial and mourning ritual that had been witnessed by Anthony Hall-Martin, a biologist who had researched elephants in South Africa for many years:

The entire family of a dead matriarch, including her young calf, were all gently touching her body with their trunks, trying to lift her. The elephant herd were all rumbling loudly. The calf was observed to be weeping and made sounds that sounded like a scream, but then the entire herd fell incredibly silent. They then began to throw leaves and dirt over the body and broke off tree branches to cover her. They spent the next two days quietly standing over 
her body. They sometimes had to leave to get water or food, but they would always return. ${ }^{28}$

There are many similar stories in which humans (rangers, explorers, zoologists) have witnessed elephants engaged in rituals of mourning while burying their dead. At the Munich Zoo, a herd of elephants were observed collectively mourning the loss of a 3-month-old baby calf named Lola. When the mother had finished saying goodbye, by laying her trunk on the baby's head, the other elephants lined up and took it in turn to lay their trunks on the baby's head. Is elephant mourning behaviour a simple reaction, or is it a response?

Elephants are regarded as one of most intelligent species on earth; their brain is very similar to that of the human brain in terms of makeup and complexity. It is thought they are equal in intelligence to cetaceans and primates. They have a wide variety of behaviours, including those associated with learning, play, altruism and a sense of humor, as well as compassion, cooperation and self-awareness. They also use tools. While high intelligence and the ability to express empathy may help to explain the elephant's ability to mourn for the dead, elephants are not alone in this regard. Other species have been observed to express emotions over the death of infants. At the Munster Zoo in Germany, an 11-year-old gorilla, Gana, would not relinquish her 3-month-old dead baby. She refused to abandon the baby, carrying it by her side for 24 hours before setting it down. Zookeepers were unable to retrieve the dead infant as she guarded it so vigilantly. Was she mourning? Scientists now say that, like elephants, chimpanzees appear to mourn their dead. Charles Choi explains how chimpanzees in a Scottish safari park responded to the last days of one of their group:

Insights into how chimpanzees respond to the death of one of their own are rare. One such instance came with the final hours of Pansy, a chimp more that fifty years old. In the days leading up to the elderly chimp's peaceful demise in 2008, her group was very quiet and moved to sleep near her, the researchers found. Immediately before Pansy died, others groomed and caressed her often. One 
male chimpanzee, Chippie, apparently tested her for signs of life as she died by closely inspecting her mouth and moving her limbs. ${ }^{29}$

Hippopotamuses have also been observed standing over the body of their dead baby for several days before leaving.

A recent event that took place in Santiago, Chile, demonstrates that some animals are both altruistic and aware of the meaning of death. The scene of a dog rescuing another dog on busy highway in Santiago was captured on a traffic camera overlooking the freeway. The rescue dog dragged its companion across lanes of traffic as cars swerved to avoid the two dogs. No motorists stopped to help. A highway crew eventually arrived and the dog was taken to the vet. What this demonstrates is that a dog will put itself in danger to rescue another from a certain death. One of the most famous rescue dogs in the Victorian era was known as 'Bob', a Newfoundland, who had been shipwrecked and took up outdoor residence on the London waterfront. Over the years he gained a reputation for saving people from drowning. Over a 14-year period he saved 23 people from the sea. Sir Edwin Landseer, the famous animal painter, painted Bob's portrait in oils. Bob sits on a quayside with the sea in the background. The painting garnered much public attention and was bequeathed to the Tate Collection. Bob was finally made 'A Distinguished Member of the Humane Society' in 1831, which entitled him to food and a medal for his bravery and services to humanity. Having been saved from a shipwreck, and certain death, Bob devoted his life to saving others in peril of drowning at sea.

The infamous story of Topsy, a four-ton African elephant from Forepaugh's Zoo on Coney Island, illustrates our own contradictory behaviour in relation to whether or not animals are sentient, express emotions and anticipate death. Thomas Edison made an early 6o-second film of Topsy's death called Electrocuting an Elephant (1903). (Figure 25) It is available for viewing on the internet. Topsy, who performed for the zoo on Coney Island, had become increasingly aggressive and killed three of her trainers over a three-year period. When her last trainer tried to feed her a lighted cigarette, she crushed him. Officials decided to electrocute Topsy as punishment. They 
BARBARA CREED : THE ELEPHANT'S GRAVEYARD

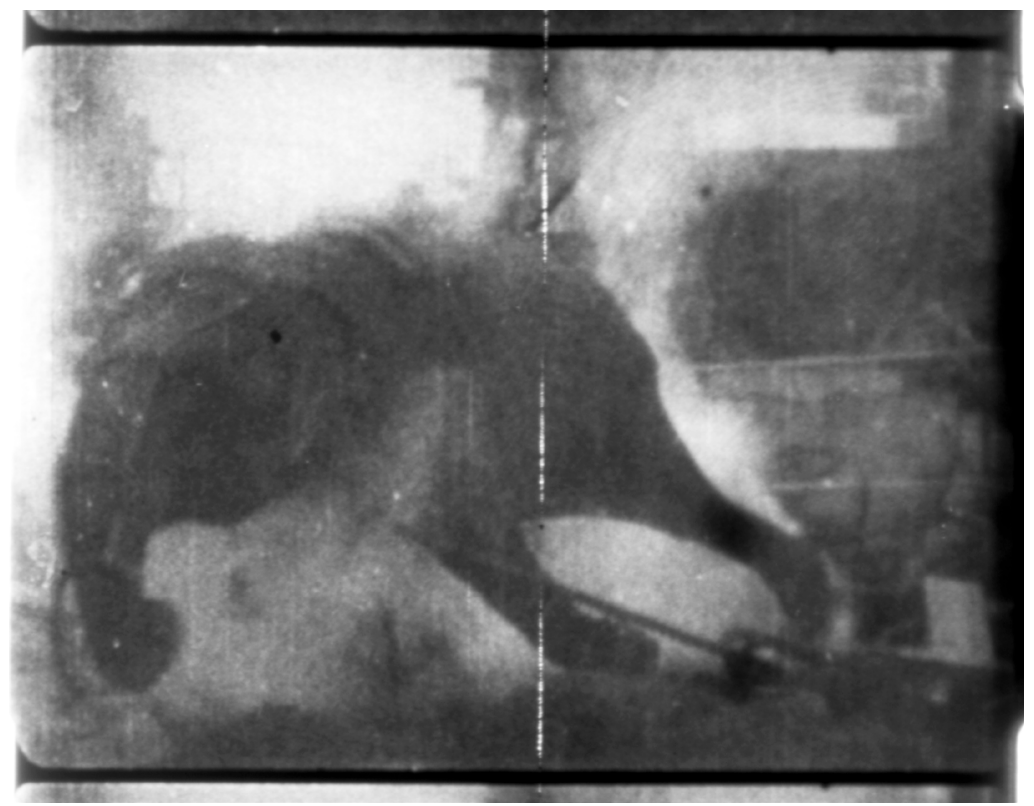

25 Topsy falling over, from Electrocuting an Elephant, dir. T. Edison, 1903 
decided electrocution, which had been used on humans since 1890, was more humane than being hanged. Besides, Thomas Edison wanted to demonstrate the superiority of his form of electricity known as the direct current over the new alternating current. In case the experiment didn't work, Topsy was also fed carrots laced with cyanide. A crowd of 1500 people paid to watch. Topsy was tied between two posts and wooden sandals with copper electrodes were attached to her feet and a copper wire run to Edison's electric light plant. A 6600-volt charge was pushed through her body. The film shows Topsy falling to the ground in a cloud of smoke. After the smoke clears we see that small spasms ripple through her massive body for up to twenty seconds. What did Topsy feel? Was there an instant when Topsy experienced a sense of fear or dread or when she anticipated or sensed her own death? The artist Sue Coe, in collaboration with writer Kim Stallwood created a series of works dedicated to Topsy. One is entitled Thomas Edison Kills Topsy the Elephant to Promote the Electric Chair (2007); it depicts Topsy chained to posts and lying on the ground as a crowd gathers in a circle to watch her execution. Coe emphasises Topsy's vulnerability, her huge body trussed and tied so tightly she is unable to move. The scene asks the viewer to wonder at the absurdity of a law that demands the brutal execution of an elephant who killed through no fault of her own.

Moussaieff and McCarthy cite the work of Cynthia Moss who studied wild African elephants for many years. She argues that elephants do have an understanding of their own death. Moss recounts a story told by R. Gordon Cummings, a nineteenth-century hunter in South Africa, who experienced difficulty in killing a large male elephant. He first shot it in the shoulder so that it couldn't run away. He then shot it a number of times in the head but with little effect. He then shot the elephant nine times behind the shoulder. Cummings said he wanted to end quickly 'the sufferings of the noble beast who bore his trials with such dignified composure'. ${ }^{30} \mathrm{He}$ wrote: 'Large tears now trickled from his eyes, which he slowly shut and opened; his colossal frame quivered compulsively, and falling on his side, he expired.' 31 Why do we have so much invested in denying that other animals understand death? 
Why have we felt a need to claim death for ourselves - to make death a mystery, a religion, a sacred journey to a new life? What would happen if we accepted that animals also understand something about the meaning of death?

\section{Artists, animals and death}

In recent years a growing number of scholars such as Matthew Calarco have argued that the human-animal boundary should be problematised and ultimately disassembled. ${ }^{32}$ In her book, Creaturely Poetics, Anat Pick argues for a 'creaturely approach' to human/animal relations based on a shared embodiedness, rather than a focus on the question of a shared subjectivity of human and non-human animals. Pick is interested in 'the corporeal reality of living bodies'. ${ }^{33}$ Her work is inspired by Simone Weil's statement: 'The vulnerability of precious things is beautiful because vulnerability is a mark of existence.' 34 Pick argues that Weil's statement is the basis of 'a radical aesthetics and an equally radical ethics'. ${ }^{35}$ Weil's concept that vulnerability is a 'mark of existence' applies to all living things, all of whom are vulnerable in the face of death. A growing number of artists in recent years have begun to explore the shared embodiedness and vulnerability of human and non-human animals. If their focus is on the bodies of animals it is because of the crucial need to undercut the anthropocentric point of view that dominates almost all intellectual discourse. Some artists emphasise the animal within the human as a way of interrogating anthropocentrism.

Janet Laurence's Stilled Lives (Figure 26) depicts a display case of dead, stuffed birds, all lying on their backs in a neatly organised row with labels attached to their bodies. The angle of the glass case creates the effect of an endless row of reflections of the dead. The birds are both still and stilled. The forlorn image of the dead bodies immediately recalls its opposite image: that of birds alive with movement and song. Stilled Lives reminds the viewer that museums collect dead creatures in order to stuff, preserve, classify, arrange and label them for display. Laurence's work offers a grim comment on the role of natural history museums that are simultaneously museums and vast graveyards of animals, which have been killed for the pleasure of the anthropocentric human gaze and the desire of 
the human to classify and label the dead. How can we wander through any of the world's famous natural history museums, vast tombs for the creaturely dead, without asking ourselves what is it about the human animal that compulsively desires to gaze on the dead bodies of non-human animals? Why do we invest so much in the dead animals and not the living? Stilled Lives also reminds us that museums are undergoing significant change. As Libby Robin states:

Animals taken originally for scientific purposes have, two centuries later, become part of an art movement that speaks to a new ethics for non-human others ... The transition of taxidermy specimen objects out of natural history and into art installation sheds light on the changing nature of museums. It also suggests that new ideas are emerging about the ethical responsibilities of people towards animals. ${ }^{36}$

Photographer Marian Drew uses her art to depict animals that have died on Australian roads, to draw attention to both the countless deaths of animals on the road and to the aesthetic and ethical conventions of the seventeenth-century Dutch still life genre. Drew arranges the dead animal on a table, set with napiery and cutlery, alongside fruit or ornamental objects as in Kingfisher with Chinese Cloth and Strawberries (2009) and Bandicoot and Quince (2006). Often the background offers a melancholy landscape. Drew arranges the dead bodies taking care to emphasise the beauty and vulnerability of the once wild, living creatures. Whereas the animals in the traditional still life were displayed to function as 'memento mori', that is, signifiers of our own mortality, Drew's haunting, uncanny images remind us of the deaths of others - the endless slaughter that takes place on our roads for which most people assume no ethical responsibility. The title of Drew's 2008 exhibition, 'Every Living Thing', emphasises the fragility and crucial importance of life to all living creatures - human and non-human alike. In Crow with Salt (2003) the dead bird lies on a china plate besides a spoonful of salt, two glass spoons filled with oil and vinegar, and a partially peeled lemon. Light suffuses the macabre scene giving the bird's black feathers a 
BARBARA CREED：THE ELEPHANT'S GRAVEYARD

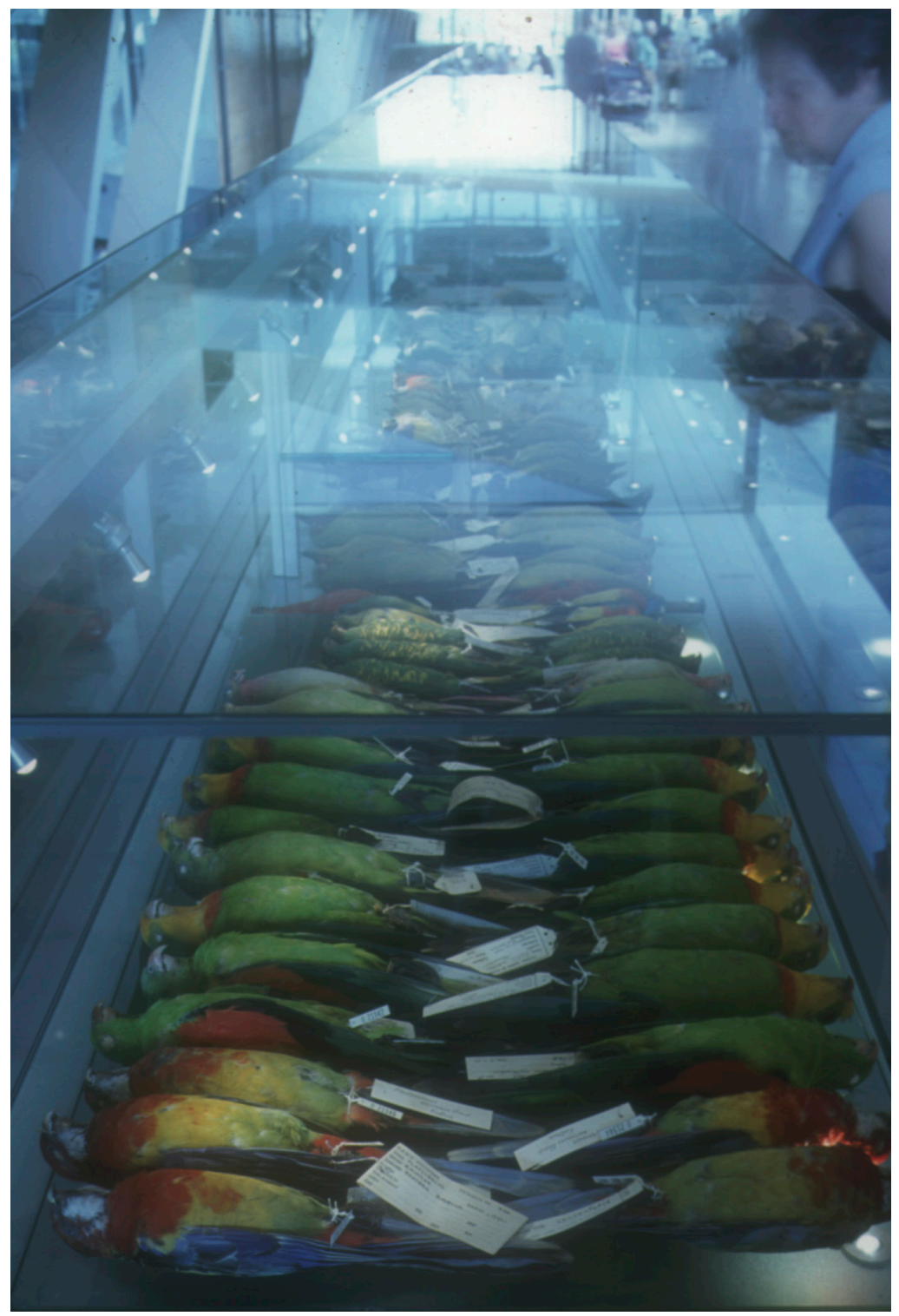

26 Janet Laurence

Stilled Lives, 2000 


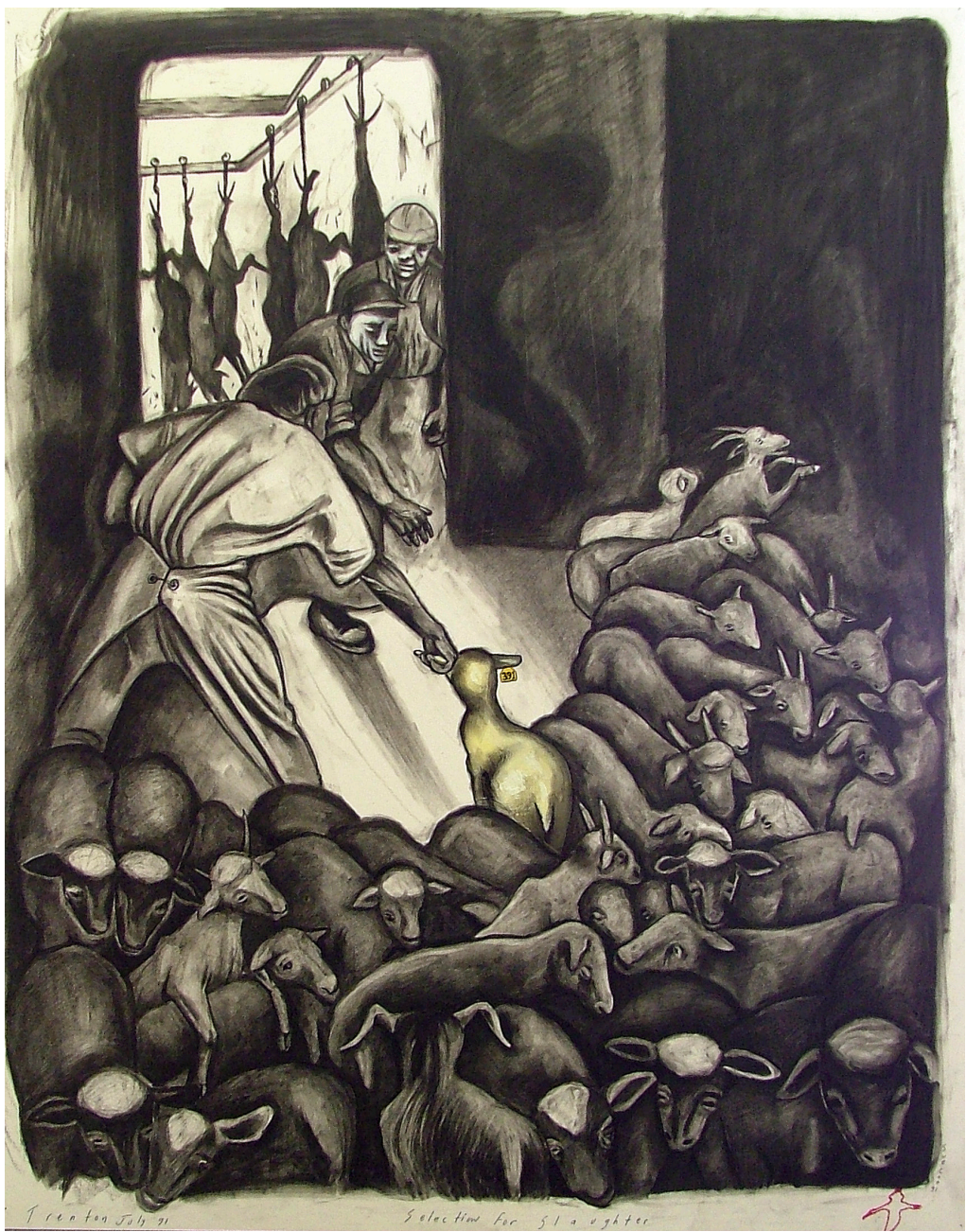

27 Sue Coe

Selection for Slaughter, 1991 
glossy sheen. The image of the crow (not normally regarded as food) recalls both the tradition of still life paintings (the creature displayed was there to be eaten) and Derrida's question: 'How does one respectfully eat the other?' 37

Michael Zavros' painting, Thoroughbred, Panthera Pardus (2010) explores the idea of animals as trophies. His painting depicts a beautiful black horse standing alert with ears pricked. The spotted skin of a dead leopard, its jaws open wide, is draped across the back of the horse with its head resting on the horse's mane. This species of leopard, which once populated many countries across Africa and Asia, is thought to be extinct. The Arabian species is close to extinction. The horse and the panther convey the impression of being companions - it is as if the horse were conveying the panther to an afterlife. Zavros' work raises the theme of trophy hunting, that is, the selective hunting of wild animals, parts of which are kept as a souvenir or evidence of the hunter's prowess. Trophy hunting is responsible for the demise of a number of endangered species such as the African lion, the brown bear and the leopard. Trophy hunters of course seek the finest specimen, which affects the gene pool and causes a decline in the size and prowess of the population. In Thoroughbred, Panthera Pardus the leopard's skin and head is preserved. Trophies are usually displayed on a wall but here the animal's skin is carefully displayed across the back of the tall elegant horse. The thoroughbred appears to be alive but it too could be a stuffed specimen. This alignment of leopard and horse is strange, even uncanny in that the familiar is rendered unfamiliar. Zavros's painting suggests a future world in which the beautiful animal exists no longer in the wild, but only as an image, which the artist has carefully preserved.

Sue Coe's work on human and animal rights issues is known worldwide. Coe's work is radical and confrontational. Her illustrations of animals in slaughterhouses directly address the issues of animal cruelty and animal death. Despite the horrific nature of her subject matter she explores these issues with sensitivity and creativity. Her photo etching Selection for the Slaughter (1991) (Figure 27) depicts a room filled with animals each waiting their turn to face death. All have turned their backs to the scene in the room at the back 
where slaughtered animals hang from hooks. Light falls on the body of a lamb whose turn has come. It stands looking into the room as one of the butchers grabs it by the ear to compel it forward. The three butchers are large able-bodied men: the lamb is small and vulnerable. Coe's illustration carefully draws the eye into the centre of the scene where light falls on the lamb's body as it awaits its fate. It is impossible to look at the scene without identifying with the lamb. In this way Coe asks us to consider the scene from the lamb's point of view, to identify with the lamb's fear which is rendered visible on the bodies and faces of the other sheep as they crowd together in the corner of the room, trying to escape the hand of the butcher. Coe's work is not easy to look at, yet it compels the viewer to look in detail. This is because Coe explores the issue of death from the animal's point of view. One particularly thoughtful work, Man Followed by Ghosts of His Meat (1990) depicts a man followed by all of the ghosts of the animals he has eaten-pigs, sheep, cattle, poultry. He stands outside a butcher's shop. A streetlight casts its rays on the group of animals who follow him like ghosts from a nightmare. The work conveys a strong impression that the man will never shake off these animals that he sees now as whole living creatures, not as pieces of meat. The idea that animals may return to haunt those who have eaten them is both sobering and darkly humorous. Coe's exhibition 'Sheep of Fools' (2005) explores the live transport industry in which thousands of live sheep are tightly packed into old freighters bound for ritual slaughter in the Middle East. The title was inspired by the sinking of a ship which was sailing from Australia to Jordan carrying sixty thousand sheep. The sheep either burned or drowned. One work depicts the sheep fighting for their lives in the water; another is a close-up of a sheep's face as it is sucked down into the abyss of black water, its eyes appearing as dark pools, against an image of the burning ship on the horizon.

In The Young Family (2002-03) (Figure 28), Patricia Piccinini explores the theme of animals and death from a very different perspective. The young family in question is an animal/human creature, a mother who lies on her side feeding her litter of babies. She has a recognisably human body but her face is porcine and her ears long and drooping. Her babies 


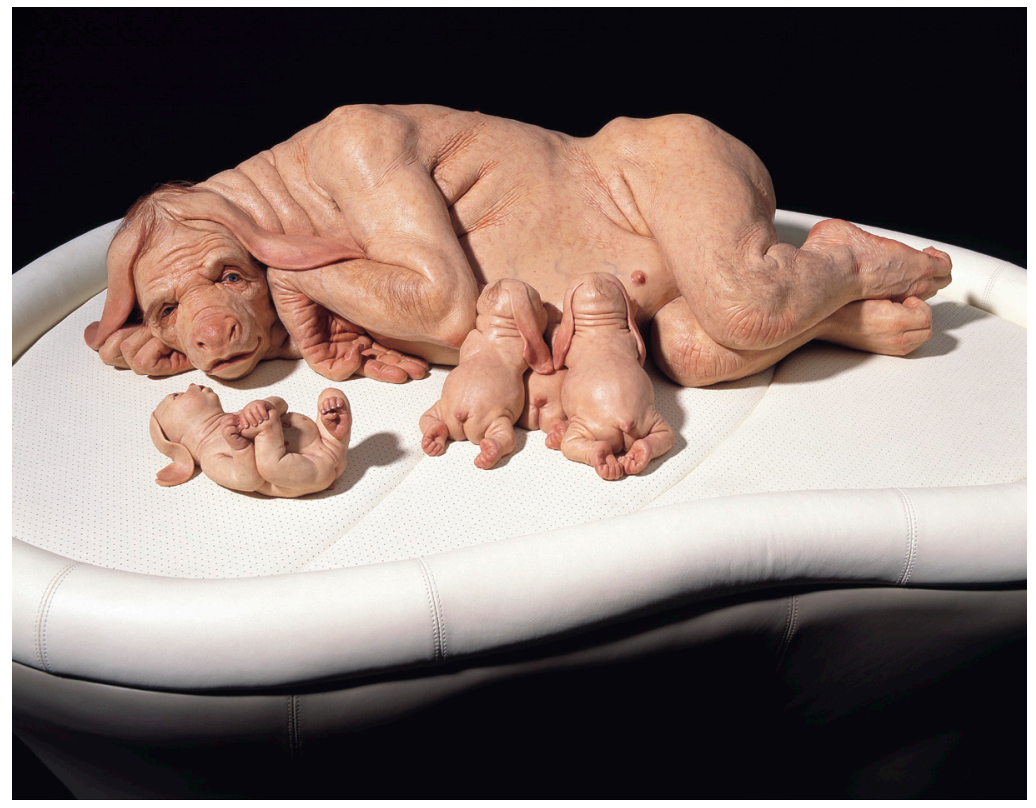

28 Patricia Piccinini

The Young Family, 2002 
are in the foreground: two suckle at her breasts while a third rolls on its back looking up at its mother with an expression of love. The mother's face in turn is suffused with concern. She is worried about what will become of her babies whom she knows have been bred to supply organs for human use. In discussing genetic engineering, Piccinini has said: 'I believe that with creation - be it parenthood, genetic engineering or invention - comes an obligation to care for the result. If we choose to customise life then we must be prepared to embrace the outcomes.' 38

Piccinini says the image is also about the animalness in us - what we share with the mother. Clearly, love is the most important emotion. The mother is filled with care and concern over what will happen to her children. What sort of responsibility do we bear to life forms we might create? What right do we have to breed other human/animal life forms in order to kill them for our own use? By representing the young family as animal/human hybrids Piccinini encourages us to identify with her and her concern for the lives of her offspring. In dismantling the human/animal boundary, Piccinini, and the other artists discussed, draw attention to the shared embodiedness and fragility of all creatures in life and in the face of death. They also explore the killing of animals as an atrocity.

The French philosopher Jacques Derrida has discussed the implications of the vulnerability of all animals in the face of death. To Derrida, the human animal has adopted various seemingly powerful measures to maintain the existence of a boundary between human and non-human animals. One of the most effective of these lines of demarcation is the view that animals do not understand the meaning of death or the darkness of the abyss. Derrida argues 'mortality resides there, as the most radical means of thinking the finitude that we share with animals ... the anguish of this vulnerability and the vulnerability of this anguish'. ${ }^{39}$ In his view, the animal is 'the absolute other' in human history. He argues that the 'most radical means of thinking the finitude that we share with animals' is to relinquish our power over them while acknowledging their vulnerability. Instead we should share 'the possibility of this nonpower'. ${ }^{40}$ John Berger believes that 
to rethink our relationship with animals in the modern era we have much to overcome. When animal and human now look at each other, Berger states, they stare across an 'abyss of non-comprehension'. 41 Yet there are many artists, writers and filmmakers who are committed to entering this abyss in order to establish a creaturely and ethical relationship with the earth's animals.

\section{Notes}

F. Nietzsche, 'Beyond good and evil', Aphorism 146 [1886], trans. Hollingdale, Gutenberg-DE <http://en.wikiquote.org/wiki/Beyond_Good_and_Evil>.

2 Ibid.

3 R. Descartes, Discourse on the Method for Reasoning Well and Seeking Truth in the Sciences [1673] The Harvard Classics 1909-14: Part V.

N. A. Rupke, 1987. Vivisection in Historical Perspective (London: Croom Helm, 1987), 26.

5 Ibid, 27.

6 Voltaire, Voltaire's Philosophical Dictionary [1764] (Fairford: The Echo Library, 2010), 14 .

7 J. Bentham, 'Limits of the penal branch of jurisprudence', The Works of Jeremy Bentham vol. 1 (London: Simpkin, Marshal \& Co., 1843).

8 C. Darwin, The Expression of the Emotions in Man and Animals (London: Fontana Press, 1999) [1889]

9 J. Moussaieff and S. McCarthy, When Elephants Weep: The Emotional Lives of Animals (New York: Dell Publishing 1995), 95-6.

10 M. Vernon, Science, Religion and the Meaning of Life (Basingstoke: Palgrave Macmillan, 2006).

11 E. A. Poe, Annotated \& Illustrated Entire Stories $\mathcal{E}$ Poems, ed. Andrew Barger (London: BottletreeBooks, 2008), 110.

12 R. Fulford, 'An infinite scream passing through nature', National Post, 12 May 2005 <http://fullcomment.nationalpost.com/2012/05/05/ robert-fulford-an-infinite-scream-passing-through-nature/>.

13 Vishwa Nirmala Dharma. 'Chakras and the channels of energy' $<$ http://www. sahajayoga.org/chakrasandsubtlebody/?mode=text>

14 J. Mills, The Unconscious Abyss (Albany: State University of New York Press, 2002), 1 .

15 Ibid., 183.

16 G. Jantzen, 'Eros and the abyss: Reading medieval mystics in postmodernity', Literature and Theology 17, no. 3 (2003): 261.

17 B. Creed, The Monstrous-Feminine: Film, Feminism, Psychoanalysis (London: Routledge, 1993), 27.

18 J. Kristeva, Powers of Horror: An Essay on Abjection (New York: Columbia University Press, 1982), 4.

19 Ibid., 2.

20 Ibid., 3-4.

21 Ibid.

22 Ibid., 117.

23 Ibid., 18. 


\section{ART IN THE GLOBAL PRESENT}

24 J. Berger, 'Why look at animals?' in About Looking (London: Writers and Readers Publishing, 1984).

25 K. Oliver, Animal Lessons: How They Teach Us To Be Human (New York: Columbia University Press, 2009), 203.

26 Berger, 3.

27 Ibid., 28.

28 M. Meredith, Elephant Destiny: Biography of an Endangered Species in Africa (Canada: Public Affairs, 2004), 184-6.

29 C. Choi, 'Chimps understand and mourn death, research suggests', Live Science $2010<$ http://www.livescience.com/6335-chimps-understand-mourn-deathresearch-suggests.html>.

30 Moussaieff and McCarthy, 134.

31 Ibid.

32 M. Calarco, Zoographies (New York: Columbia University Press, 2008).

33 A. Pick, Creaturely Poetics: Animality and Vulnerability in Literature and Film (New York: Columbia University Press, 2011), 3.

34 Ibid.

35 Ibid.

36 L. Robin, 'Dead Museum Animals', reCollections 4, no $2<$ http://www.google.com. au/imgres?imgurl=http://recollections.nma.gov.au/>, 2 .

37 J. Derrida, 'The animal that therefore I am', trans. D. Wills, Critical Inquiry 28, no. 2 (2002).

38 L. F. Orgaz, 'The naturally artificial world', $2007<$ www.patriciapiccinnini.net/ essay.php?id=29>, 11 .

39 Derrida, 396.

40 Ibid.

41 Berger, 3. 